\title{
NEW NATIVE NEUROPTEROID INSECTS
}

\author{
By NATHAN BANKS
}

The following few descriptions are based on materials gradually accumulating in the Museum of Comparative Zoology. A generic synopsis of our Capniinae, including two new genera, is based on characters that, I believe, are better than those previously used in this group.

\section{ORDER CORRODENTIA \\ FAMILY PSOCIDAE \\ Polypsocus corruptus Hag.}

In the South there are two varieties which should be named:

P. corruptus var. pictilis $\mathrm{n}$. var.

Females differing from typical corruptus in having a large pale area in middle of fore wing, similar to that of the normal male of corruptus, but more distinct; the preapical pale band is as in normal females. In male this middle pale area is more extended so as to meet the pale apical spot beyond the stigma, thus isolating the dark stigma. In none of these specimens is the stigma reddish as is common, but not constant, in typical corruptus. Size same as typical form. This form was very common in the Smoky Mountains of Tennessee, near Newfound Gap, at about 5000 feet, in September. In the valleys the typical form was common. Type M.C.Z. no. 22659.

P. corruptus var. omissus n. var.

The male differs from the typical form in lacking all pale marks in the fore wing, neither the median area nor the triangular area beyond stigma, only the minute pale dot at base of stigma, and at base of areola postica. The two males have slightly shorter wings than usual. From Great Falls, Va., 21 July, and Clarksville, Ga., 10 Aug. Type M.C.Z. no. 22660 . 


\section{ORDER PLECOPTERA}

\section{FAMILy PeRlidae}

\section{Capniinae}

The genera occurring in the United States can be tabulated as follows :

1. The radius at origin of radial sector plainly bends for-

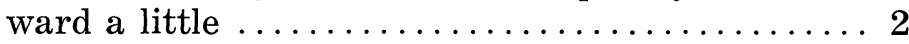

Radius at origin of radial sector straight ........ 4

2. Several cross-veins in the subapical area .... Capnoura

No such cross-veins .................... 3

3. First anal vein bends around a large triangular scar Capnia

First anal, although slightly curved, not bent around a large scar ................... subgen. Arsapnia

4. Anal area of hind wing reaches to the tip of wing Allocapnia

Anal area not reaching more than three-fourths of way to wing tip ....................... 5

5. No oblique cross-vein beyond end of the subcosta, very slender species ................... Nemocapnia

An oblique cross-vein beyond end of the subcosta . . . 6

6. Large, heavy species; setae very long, usually five or six costal cross-veins ................ Isocapnia

Slender, small species, setae very short, of only a few joints, but one or two costal cross-veins . Eucapnopsis

Isocapnia gen. nov.

Rather large, heavy species; radius not bent at origin of radial sector, an oblique vein beyond end of subcosta, several (five or more) costal cross-veins; setae long, twenty or more joints, four or five or more near base very short; anal area of hind wing not reaching to tip of wing. Much larger species than others of the subfamily.

Genotype, Arsapnia grandis Bks.

There are at least four species, Capnia crinita Claassen, 
I. fumosa, herewith described, and a clear winged species in which the radial sector is forked beyond the cross-veins; all are from the northwestern parts of United States and western Canada.

Isocapnia fumosa sp. nov.

Figure 3

Body black, posterior parts of meso and metanotum polished, legs, antennae, and setae also uniformly black. Both wings fumose, almost black on front part, the cells behind are paler in the middle, veins black. Body with only minute hairs, those on legs not half as long as in I. crinita.

Pronotum a little broader than long, scarcely at all narrowed behind.

In fore wings six to nine costal cross-veins, oblique vein arising about its length beyond the subcosta; all apical veins unforked; in hind wings several (four to five) costal crossveins, lower branch of medius forked; anal area reaches about two thirds way to tip.

The last dorsal segment of the abdomen projects at a slight angle in the middle. The ventral plate is broad and broadly rounded, each side of its median tip a ridge runs obliquely over the next segment.

Length of fore wing $16 \mathrm{~mm}$.

From Oregon National Forest, Herman, Oregon, 18 April, 1920, and Junction City, Oregon, 7 April, 1919 (both A. C. Burrill). Type M.C.Z. no. 22661.

\section{Nemocapnia gen. nov.}

Body and wings slender, radius not bent at origin of radial sector, no oblique cross-vein beyond end of subcosta, rest similar to Arsapnia; in hind wings the anal area reaches only a little beyond middle of wing; setae probably short, the joints beyond the first two three much elongate; in type species apparently but seven joints.

Nemocapnia carolina sp. nov.

Figures 1, 2, and 6

Body black, antennae and legs slightly paler, all densely 
clothed with long hair, especially long on the legs; fore wings nearly hyaline, slightly gray, veins brown, veins and margin with short hair, membrane with very minute hairs; hind wings similar. Fore wings slender, radius not bent at origin of radial sector, only one or two costal cross-veins and these near tip; no cross-vein beyond end of subcosta, none of apical veins forked, and all subparallel. Hind wings with subcosta ending before middle of wing, lower branch of medius with a long fork.

Pronotum a little broader than long, sides parallel. Setae with seven joints (possibly have been more), all but the basal two elongate, longer than in related forms.

The male has the long median piece (in the only male) projecting behind, but probably normally recurved.

Fore wing $6 \mathrm{~mm}$. long.

From Morgantown, N. Car. (Morrison), mixed in with specimens returned from a loan as "Leuctra spp.". Type M.C.Z. No. 22662.

\section{ORDER NEUROPTERA \\ FAMILY CHRYSOPIDAE}

Abachrysa gen. nov.

Body broad and heavy; antennae close together at base, not as long as wings; pronotum about twice as broad as long; fore wings with divisory cell much as in Nodita, six cubital cross-veins beyond it; costal area only moderately broad; the branches from cubitus to hind margin are in pairs, the two from each cell close together at base, or often united in one stem; the cross-vein from subcosta to radius is nearly as far out as base of divisory cell; the second cubital cell no longer than the first.

In the hind wing there is no trace of the triangle between base of radial sector and the medius, the radial sector, apparently, is here united to the upper median vein.

Genotype, Chrysopa eureka Bks.

It differs from Chrysopa and many other genera in the broad pronotum, in the short second cubital cell, in the paired branches of cubitus to margin, etc. Besides the type specimen from Arkansas, I have one collected by Prof. Frank Hull at Agricultural College, Miss. 
Chrysopa crotchi sp. nov.

Pale green. Face with two black spots each side, one under eye near to clypeus and one at outer side of clypeus; palpi pale, unmarked; antennae wholly pale, the basal joints rather short, antennae much shorter than fore wings; pronotum much broader than long, hardly narrowed in front, unspotted.

Wings moderately long, almost acute at tips. Fore wing with costal area rather narrow, divisory veinlet ends beyond the cross-vein, eight cubital cross-veins beyond it; radial sector but slightly curved, fifteen radial cross-veins; the gradate veinlets in even and nearly parallel series and parallel to outer margin, about ten in each row, post-cubital area nearly twice as wide as cubital; veins greenish, most of the costals marked with black toward base, some radials with short dark mark, basal vein from cubitus to anal black, and the gradates dark; hairs on veins short, on costals hardly one-half a cell's width; stigma pale green, not prominent.

In hind wings the costals, radials, and gradates also partly dark, eight cubital cross-veins, fifteen radials.

Length of fore wing $16 \mathrm{~mm}$., width $5.5 \mathrm{~mm}$.

From Victoria, Vancouver Island, July (Crotch). Type, M.C.Z. No. 22975.

\section{ORDER TRICHOPTERA}

FAMILY LIMNEPHILIDAE

Dicosmoecus obscuripennis sp. nov.

Figures 4 and 5

Face yellowish, vertex black, both with black hair; antennæ brown, black on basal joint; palpi brown, paler on base; thorax black, pro- and mesonotum with yellowish hair; abdomen dark brown; legs brown, rather paler toward tips, spurs brown, spines black. Fore wings uniform brown (darker than in D. tristis), dot in base of fork two only distinct darker mark, veins yellowish, hairs mostly erect and black; hind wings paler brown, almost yellowish toward base.

Fore wings a little broader than in $D$. tristis; venation of both pairs practically the same as in $D$. tristis. 
The male genitalia have the lower appendages widely outspread, the apical part about as slender as in D. tristis and with a sharp point; the superior appendages are much smaller than in $D$. tristis, slender, cylindric, scarcely clavate, while in $D$. tristis they are fully twice as broad and flattened and near tip roundedly widened.

Fore wing $19 \mathrm{~mm}$. long, $7 \mathrm{~mm}$. wide.

From Alaska. Type M.C.Z. No. 22658.

FAMILY LePTOCERIDAE

Arthripsodes slossonae sp. nov.

Figure 7

Body yellowish brown; antennae dark, each joint pale on base; hair on head mostly pale, but a large tuft of dark hair each side in front of eye and below antenna, and some dark on posterior warts, thoracic notum mostly with pale hair, some dark near sides; legs pale; front legs of male with the tibiae dark on inner sides, and also the tips of tarsal joints dark. Fore wings a nearly uniform yellowish brown; a snow white mark at the end of anal vein, one at base of the stigma, and faintly over end of discal cell; hind wings gray, unmarked.

In fore wings the median cell does not reach nearly as far basally as the discal cell (more subequal in transversus).

The male genitalia has the clasper much as in $A$. transversus, the apical segment a little shorter, but the curved appendage is here very much shorter and stouter toward base; in length but little, if any, more than one half of the apical segment; each side of the base of the penis is a lobe fringed with stout bristles (not in $A$. transversus).

Length of fore wing $10 \mathrm{~mm}$.

From Bellaire, Florida (Slosson) and Harrisburg, Pa., 13 July (Champlain). Type M.C.Z. No. 22655.

FAMILY HYDROPHYCHIDAE

Hydropsyche carolina sp. nov.

Figure 8, 9

A small species with the penis of the depravata type. Head and thorax dark, head with white hair, thorax in front 
with pale yellowish hair; antennae pale, obliquely dark on joints as usual; palpi a little brownish ; legs very pale, rather brown on tarsi, hind tibiae with long white hair, spurs pale; abdomen dark brown above, paler beneath, a white lateral stripe where dorsum and venter meet.

Fore wings mostly clothed with brown hair, dark at stigma and toward tip, a curved row of white spots, often united in a band, across the apical cells, a whitish spot before the stigma, an elongate white spot somewhat before outer angle, not extending upward beyond median vein, and a little before it is another white spot, sometimes the two nearly connected.

The male genitalia have an angular incision in the superior plate, the apical part of clasper is slender and curved; the penis, seen from side, is enlarged at tip, mostly on lower side.

Fore wings $7 \mathrm{~mm}$. long.

From North Carolina (no further locality). Type M.C.Z. No. 22657.

Of the size of $H$. phalerata, it is readily separated by the differently marked wings, and by the very different genitalia.

\section{Explanation of Plate XI}

1, Nemocapnia carolina, ventral plate; 2, Nemocapnia carolina, fore wing; 3, Isocapnia fumosa, ventral plate; 4, Dicosmocus obsuripennis, genitalia, side ; 5 , Dicosmocus obsuripennis, genitalia, below ; 6 , Nemocapnia carolina, male venter, below ; 7, Arthripsodes slossonx, genitalia, below; 8, Hydropsyche carolina, clasper and penis; 9, Hydropsyche carolina, superior plate, above. 

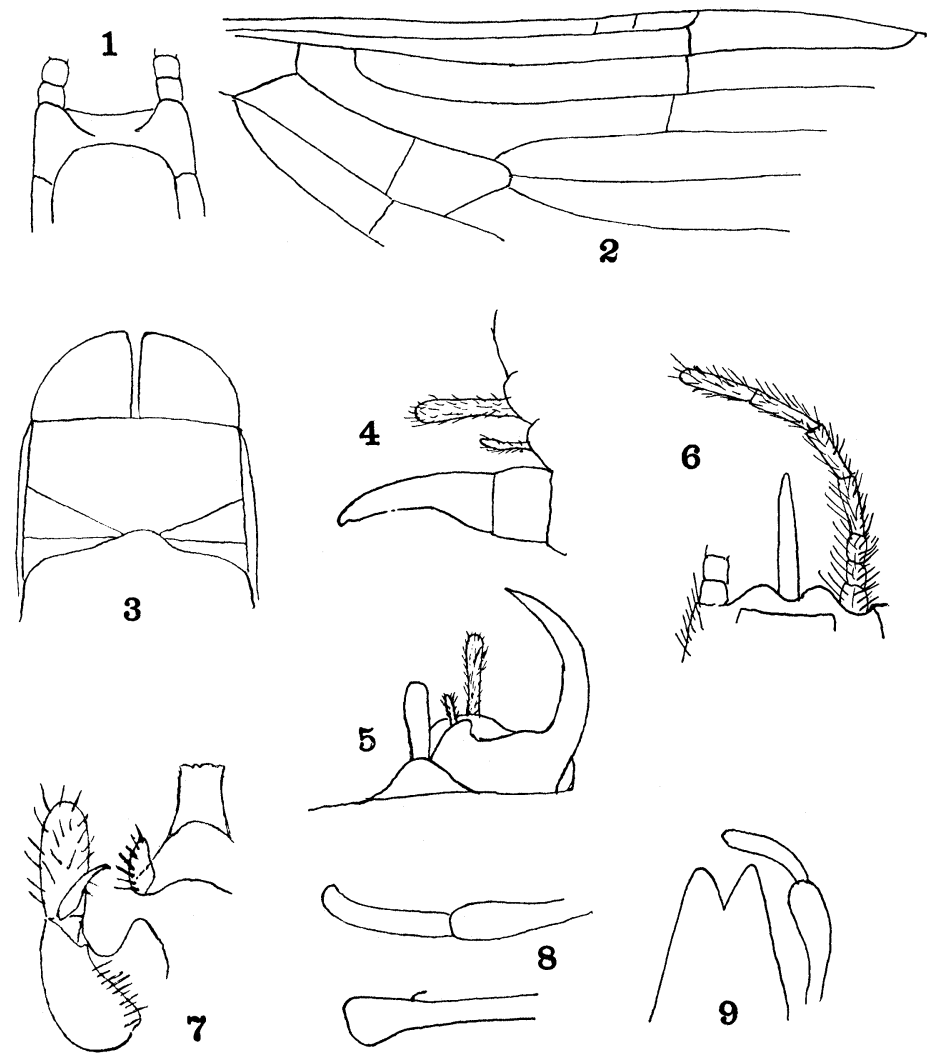

Banks - New Neuropteroid Insects 

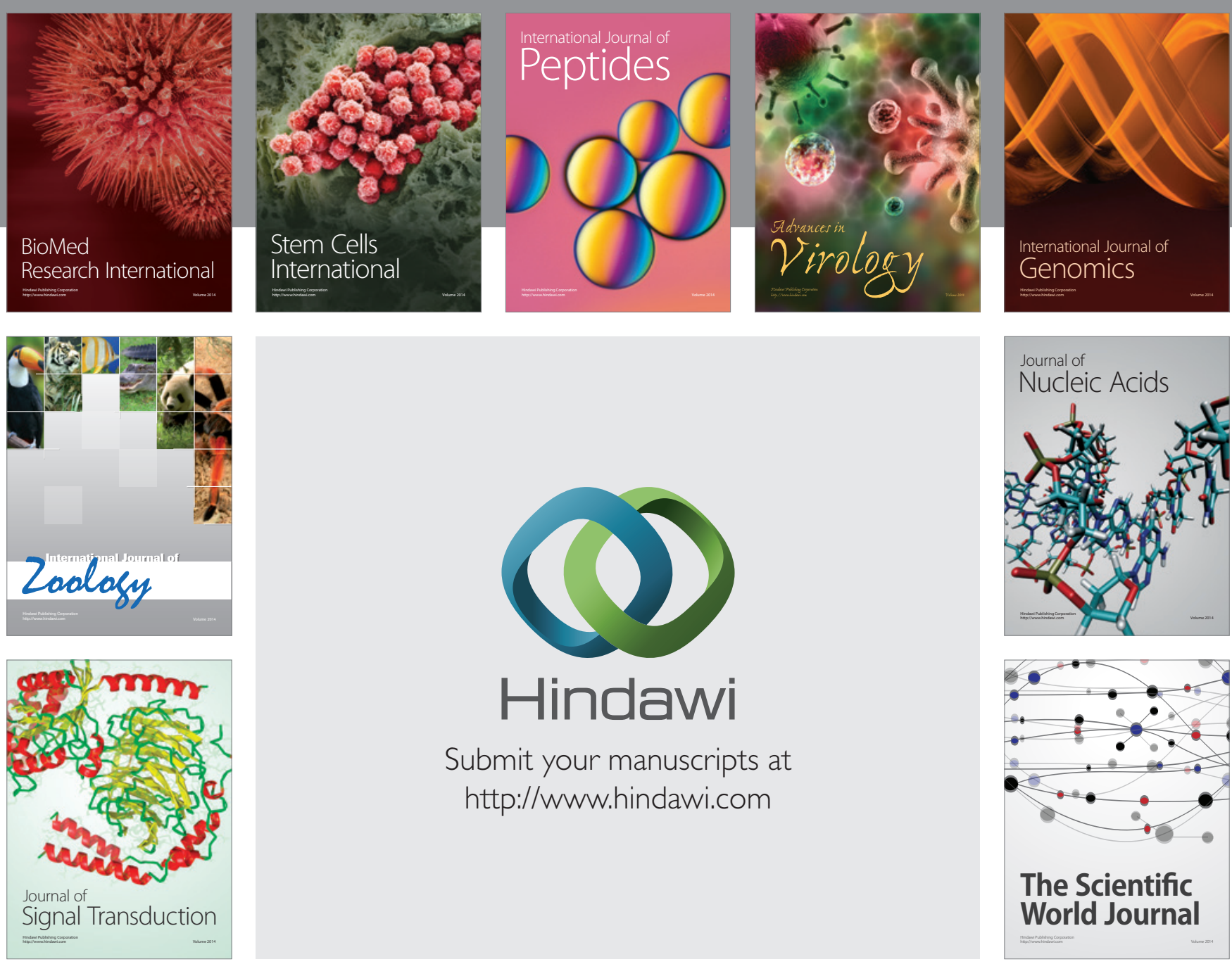

Submit your manuscripts at

http://www.hindawi.com
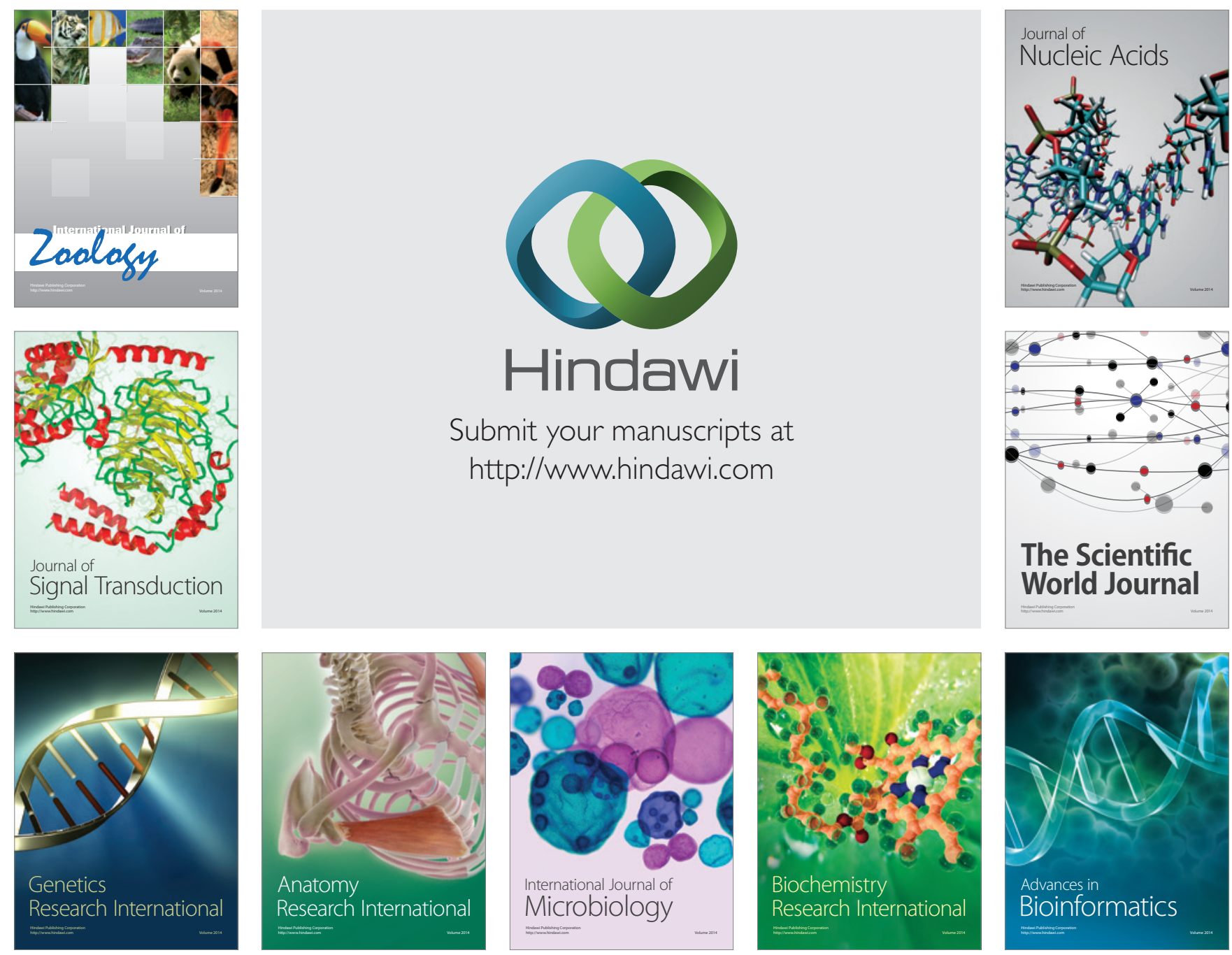

The Scientific World Journal
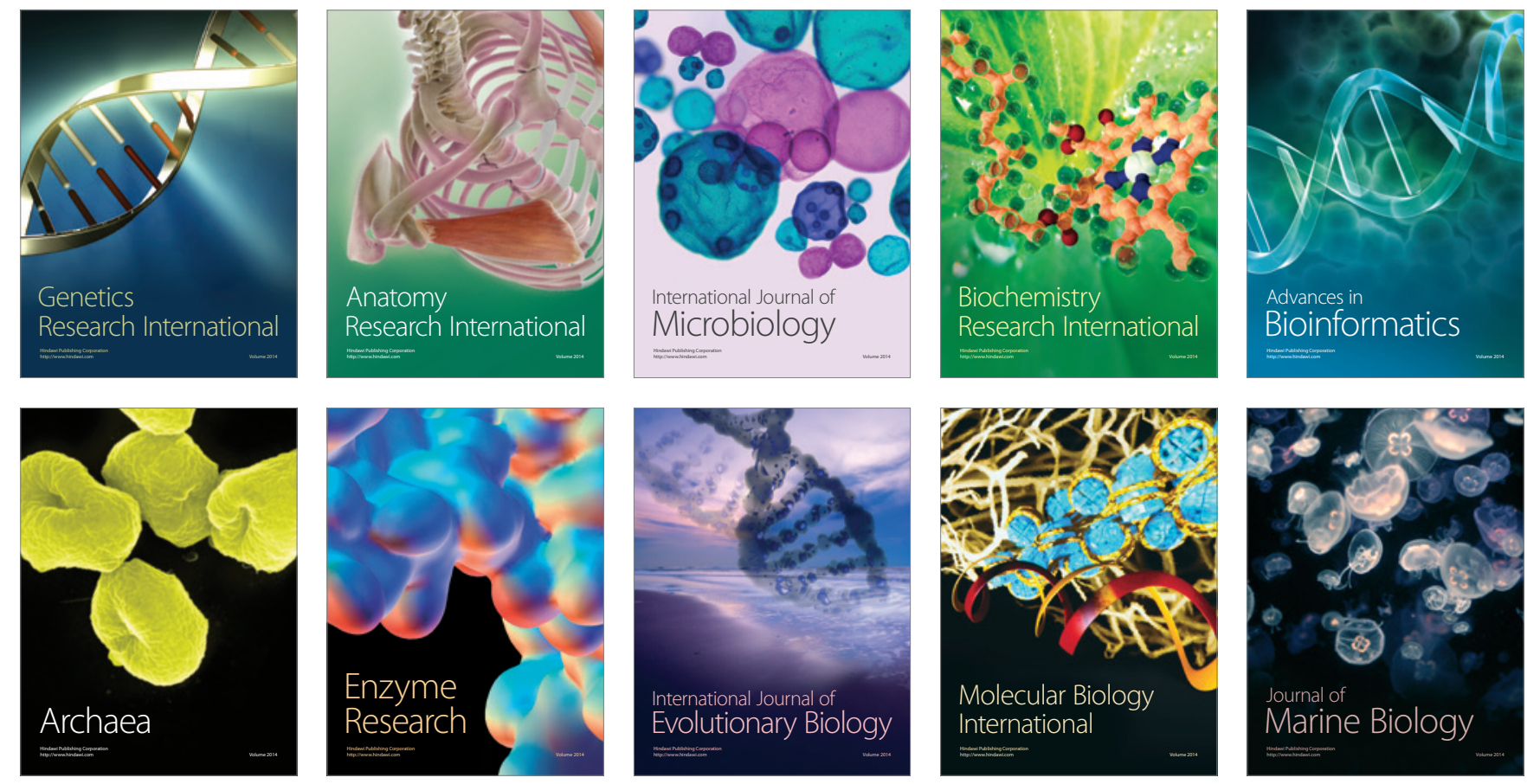